\title{
EM BOA COMPANHIA
}

você ri, eu sei que pode ser engraçado, tem moleque que faz isso, sentado um bom tempo sobre a mão, até adormecê-la de todo, entáo uma punheta pela mão da moça tal, ela bem ali, outra nele mesmo, os olhos fechados, fazendo as suas vontades melhor do que ele próprio faria quando faz, ou do que ela, se fizesse de verdade, mas o ermelino não é mais criança, sei, sei, todo mundo sabe que ele tem problema, não bola muito bem, ninguém liga, essa é a verdade, ninguém ouve, ninguém está nem aí com ninguém, isso é que é, nesse caso só eu, fazer o quê?, escuto o coitado por uma espécie de dever de ofício, não é assim que se diz?, é, é, um coitado, sim, se abriu comigo porque sente que dou alguma atenção, o que nem é certo, converso mais ou menos com ele porque tenho de entrar no almoxarifado duas ou três vezes por semana, pego o que tenho de pegar, assino o papel e disfarço meia dúzia de palavras, é, um pouco de medo, também, afinal, falam tanta coisa, vai saber, o homem trancado ali sozinho, listando aquele mundo de coisas, só podia mesmo que birutar, não acha?, bom, é parente do homem, sim, a solange confirmou, mas faz o que tem de fazer, concorda?, é mais fácil você tomar o pé na bunda, espertão, bem, somando tudo o que conversamos lá dentro, nesses anos todos de firma, dá uma conversa só, acredita?, não pelo pouco do amontoado, mas pelas continuaçóes sempre de onde paramos exatamente o diálogo, na maioria das vezes nem me lembro, ele faz um apanhado, então, e retoma certinho, avança um bocado, dou a trela medida, pro troço não desandar demais, sei lá, aqueles montes de estantes e caixas, sabe como é, né?, negócio estranho, confesso, a sensação de que nos encontramos uma única vez, percebe?, pô, sinvaldo, você fica com essas frescuras de transforma-se o amador na coisa amada, porra, é sério, ele é sozinho no mundo, mesmo no meio de tanta gente, no fundo você também é, eu sou, mas não sabemos, ou sabemos escondidos de nós, essa é a verdade, para de rir, cacete, ele já tentou se matar, todo mundo sabe disso, uma perna já pra fora da janela, ia pular, não deixei, tive que fazer força, mesmo, ele ia, sim, vocês é que inventaram história, disseram que ele estava me esperando, e coisa e tal, que homem que é homem se mata sem volta, que não é essa coisa de mulher, que toma comprimidinho pra não encarar o fim e acaba no hospital, fazendo faxina no estômago, não sei, pode até ser, como é que você tem coragem de troçar de novo?, olha, vou ser bem sincero com você, no fundo, às vezes, naqueles dias fodidos em que a gente fica com a pá virada, sabe, até tenho vontade, também, mas falta a coragem, diz que você nunca pensou, ah, não vem com essa, não, não é só questão de loucura ou macheza, não, pra falar a verdade eu tenho sim um puta respeito por um cara que tem colhão de meter um ponto-final nessa porra, e, que amor o quê, rapaz, vai tomar no cu, sinvaldo, vê se leva alguma coisa a sério na vida, caralho, concordo que o ermelino seja meio estranhão, mas, olha, na semana passada é que ele me contou essa história, você fica brincando, quase me esqueci do principal, é, foi do jeito que o carlos contou, mesmo, até me arrepio, olha, coloquei o material no carrinho, ia dando a corda de sempre na conversa, patati, patatá, o calor à noite, comentei minha dificuldade em pegar no sono, andava dormindo mal, mesmo, então ele me segredou que já não tem mais problema de insônia, fica deitado sobre o braço toda noite, bastante tempo, soltando o peso de acordo, estancando bem a circulação, depois se vira, coloca aquela mão adormecida, insensível e estranha no rosto, devagar, disse que só então consegue fechar os olhos sem medo, que só desse jeito passou a dormir de um sono só, a noite inteira, um novo homem depois que descobriu isso, fala que não é esquisito, fala que não é triste, fala

Antonio Geraldo Figueiredo Ferreira nasceu em Mococa, SP. Estudou na USP, onde se graduou em letras e ingressou na pós-graduação. Na década de 1990, abandonou a academia e foi morar em Arceburgo, MG. Publicou o livro peixe e míngua, poemas (Nankin Editorial), e outros textos em jornais e revistas. Os fragmentos acima foram retirados do livro as visitas que hoje estamos (Editora Iluminuras), recentemente publicado. 